\title{
Economic Empowerment of Rural Women: Case Study of Microfinance Institution (MFIs) in Tangerang, Indonesia
}

\author{
Mukhaer Pakkannaa ${ }^{a}$, Lincolin Arsyad ${ }^{b}$, Agustinus Suryantoroc
}

\begin{abstract}
The aim of this research is to extract information from married female clients who utilize financing, empowering, and other facilities provided by Microfinance Institutions (MFIs). Quantitative descriptive approach is used in order to describe MFIs. Specifically, the difference between MFIs in each area will be overviewed by using statistical instruments of testing for a difference between means and independent F-test. On the other hand, descriptive qualitative approach is used to review the social interactions of female clients. The results of this research have uncovered some facts. First, however, Difference-Between-Two-Means Test has revealed that no significant difference is found. This shows that the empowering aspect that has been done by MFIs conforms with the standard. Second, the fact that no significant difference is found in the empowering process has been backed by data that reveals relatively small loans scale, similarity in business models, unvaried necessity, relatively small expenditure and living cost, low access to education, and good accessibility to MFIs. Third, business models that are desirable by female clients have these characteristics: only requiring a minimum amount of capital; durable; fast-moving; focusing more on costumers; adaptable; contributing to the society's economy; flexible; having a set amount of freedom.
\end{abstract}

\section{Keywords}

Women empowering, Microfinance Institutions (MFIs), fishermen society, agricultural society, industrial area

Many evidences have shown that Microfinance Institutions (MFIs) are capable to reduce poverty in rural areas (Aruna and Jyothirmayi 2011). Leikem (2012) has conducted a study based on Gonzalez's (2008) data of 2,420 MFIs, representing 99 millions clients over 117 counries. The rate of loan repayments from those clients, who in fact do not hand over collaterals, exceeds 95\%. MFIs can also access hard-to-reach areas, something which formal finance institutions cannot do. Moreover, Velasco and Marconi (2004) explained that MFIs have more flexibility to keep in touch with their clients than common finance institutions. One method that MFIs do to gain that advantage is by utilizing social capital based on social groups approach as a replacement for collaterals (Mosley and Rock 2004; Chowdhury, Mosley, and Simanowitz 2004).

The same condition applies in Indonesia. Many

\footnotetext{
aAhmad Dahlan School of Economics (STIEAD), Indonesia bGadjah Mada University (UGM), Indonesia

cSebelas Maret University (UNS), Indonesia

\section{Correspondent Author:}

Mukhaer Pakkanna, Jl. Ciputat Raya No. 77 Cirendeu, Jakarta Selatan, Indonesia, 15419

E-mail:mukhaer@stiead.ac.id; mukhaer_p@yahoo.com
} 
studies agree that MFIs are sources of financing that can be acquired easily. BRI-Unit Desa has given us valuable lessons in the study of MFIs, as Hartungi (2007) said in his study. As an MFI, BRI-Unit Desa has been providing financial services to remote areas with market rate interest, and no subsidy is required. Empirically, MFIs have noticed the quality of service in a way to know the persons more closely and understanding the needs of its customers, so that the MFI's clients have an excellent rate of return and cash flow healthy customers as a substitute for physical collateral. In addition, group approach (joint responsibility) is also proven to be effective as pressure group, as well as capable of reducing cost and risk in loan distributions.

In his study, Arsyad (2005) also observed positive influences that MFIs have in increasing socio-economic conditions of the poor. That influence can only be maintained if MFIs have good performance and wide outreach. By using study case approach in Gianyar Regency, Bali, Arsyad's study has found that informal institutions (e.g., values, norms, and social sanctions) have an important influence for the governance of Rural Financing Institutions (Lembaga Perkreditan Desa-LPD), covering organisation, recruitment procedure, saving and loans mechanism, and remuneration system. Together with informal institutions, formal institutions also have direct influence to the governance of LPD.

By considering that poverty thrives more in rural areas, the focus point to combat the problem starts in this very rural areas. According to the World Bank (2010), around $82 \%$ of the poor live in rural areas. The residents of poor villages are mostly farmers who face challenges in developing their livelihood. Those challenges are: (1) limited and damaged natural resources; (2) uncooperative and limited policies regarding the development of production technology; (3) poor infrastructure (transportations) and limited support from development-supporting institutions (education, health, investation); (4) marginalized society and culture (rights to land and tenure) and limited possibility to develop local economy.

Meanwhile, the most critical layer of poverty in rural areas is the poor women. To an extent, poverty has been largely associated with women's livelihood. The spreading of sexual assaults, prostitutions, migrant workers, human traffickings, and other crimes has indirectly been attributed to poverty of women. Ironically, women, who make up $52.7 \%$ of the world's population, only have one thousandth of world's total wealth, and they only receive $10 \%$ of total wages (The Millennium Development Goals Report 2010).

From that data, many studies have focused their analysis in reviewing the role of MFIs in combating poverty of women in rural areas. Mayoux's (1999) study elaborated MFI's roles on women empowering in some parts of Africa (Cameron, Zimbabwe, South Africa, Kenya, and Uganda), with Sudan as the benchmark in the empowering of microfinance's female clients. Mayoux argues that the main hypothesis of women empowering is that women are the core of families. By declining the poverty rate of women, poverty rate in general should also be reduced. By case study approach, microfinance programs in some sample countries in Africa has contributed in changing gender roles and issues. With women as the focus of microfinance access, the economic condition of women has also developed even more (Tundui and Mgonja 2010; Ifelunini and Wosowei 2013).

By following the same train of thought, Noreen (2011) has conducted a study in Bhawalpur District, Pakistan. The study elaborates its data by categorizing female and male clients. The results show that female clients have better use in spending the loans, as well as shows better rate of loan repayments. The only disadvantage of female clients is that they have lower education and skill than their male counterparts. By reflecting to Noreen's study, Altay (2007) also found the same facts in Turkey. 
According to Altay, Turkey is one of the countries that are late in raising awareness about the utilization of MFIs, especially after the great earthquake in 2000. However, in a decade, MFIs have provided significant benefits for the prosperity of families, especially regarding loans that are provided for female clients. The main argumentation of MFIs giving important roles for female clients is because it is considered as an equitable action, and women can utilize the loan and manage families' income better than men.

According to UN (United Nations) statistical data of 1995-2000 in Nitin Bhatt and Shui-Yan Tang (2001), the rate of loan repayments for microfinance programs targeted at women has exceeded $90 \%$. On the other hand, Rajivan's (2001) research on the same topic in Indonesia has showed similar result, with 91\% rate of loan repayments, whereas the rate of loan repayments for male clients is only $80 \%$. This average number of around $90 \%$ loan repayments of women clients also occurs in India. This high rate of loan repayments has made policy makers, including donor agent, believe that MFI with women as target group is a financially sustainable economic operation.

\section{THEORY AND HYPOTHESIS EXPANSION}

\section{Empowerment}

According to Merriam Webster dan Oxford English Dictionary in Prijono and Pranarka (1996), the word "empower" has two meanings: (1) to give power or authority to; and (2) to give ability to or enable. The first meaning has a sense of transfer of power or authority delegation, while the latter emphasizes the bestowment of an ability or power. These two meanings are the main reasoning behind the importance of women's role empowerment (Rowlands 1997; Luttrell et al. 2007).

On the other hand, the concept of empowerment, in its core, has the concept of economic development which crystalizing social values. This concept reflects a new paradigm of development, which is people-centered, participatory, empowering, and sustainable (Kartasasmita 1996; Jupp, Ali, and Barahona 2010). The concept is more general than a specific purpose of meeting basic needs or providing mechanism to prevent further progress of poverty (safety net) (Eyben, Kabeer, and Cornwall 2008).

Friedmann in Kartasasmita (1996) argued, "The empowerment approach, which is fundamental to an alternative development, places the emphasis on autonomy in the decision-marking of territorially organized communities, local self-reliance (but not autarchy), direct (participatory) democracy, and experiential social learning”. Therefore, women empowerment cannot be viewed exclusively from economic dimension.

First, women empowerment starts by creating a suitable climate for the development of women's ability (enabling). The quintessence of women empowerment is that all women are capable of developing their abilities and skills.

Second, women empowerment needs to strengthen women's potentials. It covers real actions to provide women with supplies of input and opening access to various resources. In this case, input means everything from infrastructures and social institutions to funding. Meanwhile, access is focused for chance to develop communication, network, and possibilities.

Third, women empowerment provides protection and aid for rural women (Kartasasmita 1996; Sumodiningrat 1998).

\section{Rurals as Poverty Enclaves}

A study conducted by the International Fund for Agricultural Development (IFAD), which concentrates in agrarian developing countries, shows that $75 \%$ of poverty is situated in the rurals (The International Fund for Agricultural Development [IFAD] 2009). To some degrees, Todaro and Smith (2006) ran a similar study in African and Asian countries, yielding result that shows $80 \%$ of poor 
groups are located in rural areas. According to Todaro, the biggest part of government spending in developing countries for the last quarter-century, ironically, is splurged to urban areas and their economic sectors, e.g., modern manufacturing and commercial sectors.

Then, how about the situation in Indonesia? Generally, some data agree with previously explained facts and reasonings. First, the population in rural areas is increasingly getting higher. In 1980, $77.6 \%$ of the population lived in urban areas, and then it decreased to $69.1 \%$ in 1990 , until it reached only $50.3 \%$ in 2010. Second, the number of poor people in rural areas is higher than in the urbans. On March 2010, there are 18.97 millions of poor people in 17,220 villages, while 11.05 millions poor people in the cities. Meanwhile, in 2011, there are 19.93 millions of poor people living in the villages, while the cities have 11.10 millions of people.

According to the data from State Ministry for Acceleration of Development in Underdeveloped Regions (Report of the Ministry of Rural Development [KPDT] 2008), there are 38,232 villages (54.14\%) that belong to the category of developed regions. In that category, 36,793 villages (52.03\%) are in developed state, and 1,493 villages (2.11\%) are in very developed state. Meanwhile, in the category of underdeveloped regions, there are 32,379 vilagges (45.86\%), in which 29,634 (41.97\%) of them are in underdeveloped state, and the last 2,745 (3.89\%) are in very underdeveloped state. Underdeveloped regions are characterized from villages that have limited access to roads, health services, permanent markets, and electricity. The average of poor families in underdeveloped regions are $46.44 \%$, and National Development Index (IPN) of those villages are 66.46\%.

According to BPS (Badan Pusat Statistik/Central Bureau of Statistics) (2011) in Indicators of Women's Social, there are $63.54 \%$ female residents who have main occupation in rural areas, while for their male counterparts, there are $61.43 \%$. Besides that data (BPS
2011), it is also shown that women controls $44.29 \%$ of micro-industry ownership in Indoensia (micro-industry only makes up $10.28 \%$ of national industry). Although it shows smaller figures compared with men's ownership of micro-industry (52.21\%), it is believed that the actual percentage for the women should be higher since Indonesia Statistics' data is based only on formal ownership, not the actual transactions makers.

\section{Hypothesis Expansion}

In order to review the differences among each rural areas (fishery, agriculture, and industry), analysis design is used with the following formulas: Empowering aspect of MFI's member in the fishery (X1), industry (X2), and agriculture (X3). Therefore, two hypotheses can be formulated.

H0: No significant difference is found in the quality of empowerment among semi-formal MFI's members in the areas of fishery, agriculture, and industry.

H1: Significant differences are found in the quality of empowerment among semi-formal MFI's members in the areas of fishery, agriculture, and industry.

\section{RESEARCH METHOD}

\section{Research Locations}

The research is conducted in three rural categories from 23 districts in Tangerang Regency: (1) fishery, which is situated in Pakuhaji, Teluk Naga, and Mekar Baru; (2) agriculture, which is situated in Panongan, Cisauk, and Tigaraksa; and (3) industry, which is situated in Jayanti, Kelapa Dua, and Bina Sejahtera. There are nine surveyed MFIs in each locality.

\section{Research Samples and Informants}

In order to review and determine whether empowerments and loan facilities for women do have benefits or not, 180 respondents from those three areas 
in Tangerang Regency are selected. The selected respondents will be considered representing the population and in some way having knowledge regarding the topic of the research. Purposive sampling is used to gather information regarding whether there is any benefits from the loan and empowerment facilities.

\section{Analysis Instruments}

The instrument used in this research is Difference-Between-Two-Means Test with independent F-test or one-way analysis of variance (ANOVA). Independent F-test is a type of statistical test with the purpose of comparing the average between two unpaired/unrelated clusters in a same group. Unrelated, in this case, means that the research is conducted to analyse two different subject samples. That design is known as one-way ANOVA since it will test the comparative hypothesis of three samples (fishery, industry, agriculture).

\section{DATA ANALYSIS}

According to the analysis design, empowerment aspect of semi-formal MFIs (koperasi) clients in fishery (X1), industry (X2), and agriculture (X3) can be seen as follows (see Table 1 ).

By using Difference-Between-Two-Means Test, the data for empowerment in each area are gathered by utilizing the following formulas: Sum of Average Quadrat (JKR), Sum of Total Quadrat (JKT), Sum of Quadrat between Groups (JKA), Sum of Quadrats in-Groups (JKD).

$$
\begin{aligned}
& n a=3, n 1=n 2=n 3=60, N=n t=180 \\
& J K R=\frac{\left(\sum Y_{t}\right)^{2}}{N}=1,218,205 \\
& J K T=\sum Y_{t}^{2}-J K R=7,905.2 \\
& J K A=\sum \frac{\left(\sum Y_{i}\right)^{2}}{n_{i}}-J K R=42,033 \\
& J K D=J K T-J K A=7,863.17
\end{aligned}
$$

With Degrees of Fredoom (dk) or (db) calculated as follows:

$$
\begin{aligned}
& d b(R)=1 \\
& d b(A)=n a-1=2 \\
& d b(D)=n t-n a=177
\end{aligned}
$$

Thus, the ANOVA table will look like Table 2 as follow.

From the list of distribution table $\mathrm{F}$ with $\mathrm{dk}$ numerator of 2 and dk denominator of 177 in level of significance of .05 and $.01, \mathrm{~F}$ hit $<\mathrm{F}$ table is yielded. Therefore, H0 is accepted. This result shows that no significant difference is found in the quality of empowerment among semi-formal MFI's members in the areas of fishery, agriculture, and industry.

\section{RESULTS}

Some results and facts can be concluded from the research.

\section{Facilities Utilization}

These results will show the difference in the performance of each members/clients in utilizing the fundings and loans, empowerment facilities, and other services provided by semi-formal MFIs. Although from the background profiles, we can learn that each area has its own advantages, disadvantages, and uniquenesses, Difference-Between-Two-Means Test or analysis of variance (ANOVA) has proved that there is no significant difference in the process of empowerment. Furthermore, the result indicates that empowerment aspect done by the semi-formal MFIs conforms to the standard (institutionalistic), such as standard of rules, similarity in funding schemes, standard operating procedure (SOP), low-cost funding, etc. In addition, the fact that no significant difference is found in the empowering process has been backed by data that shows relatively small loans scale, similarity in business models, unvaried necessity, relatively small expenditure and living cost, low access to education for the children and family members, and good accesibility to semi-formal MFIs. 
Table 1. Design of Comparison Between the Areas

\begin{tabular}{llll}
\hline \multirow{2}{*}{ Number } & \multicolumn{2}{c}{ Client's areas } \\
\cline { 2 - 4 } & Fisheries (X1) & Industry (X2) & Agriculture (X3) \\
\hline 1 & $Y$ & $Y$ & $Y$ \\
2 & $Y$ & $Y$ & $Y$ \\
3 & $Y$ & $Y$ & $Y$ \\
$\cdot$ &. & $\cdot$ &. \\
20 &. & $\cdot$ & Y \\
\hline
\end{tabular}

Table 2. List for the Analysis of Variance (ANOVA)

\begin{tabular}{lllllll}
\hline Source of variant & $\mathrm{Db}$ & $\mathrm{JK}$ & $\mathrm{RJK}$ & $\mathrm{F}$ hit & .05 & F table \\
\hline Average & 1 & $1,218,204.8$ & $1,218,204.8$ & & & \\
Between groups & 2 & 42.033 & 21.017 & .473 & 3.00 & 4.61 \\
In groups & 177 & $7,863.17$ & 44.425 & & \\
Total & 180 & $1,226,110$ & - & & \\
\hline
\end{tabular}

\section{Empowering Aspect}

By focusing on empowerment aspects that covers enabling, empowering, and advocation, we can see that empowerment has progressed according to the concept formulated by the semi-formal MFIs. However, it can still benefit from optimalization and improvement, especially if the concepts of empowerment formulated by Kartasasmita (1999), Sumodiningrat (1998), Williams, Seed, and Mwau (1994), and Betata (2007) are to be used.

On the aspect of enabling, it is concluded that fishery society generated the highest point in the perception of enabling, compared with other areas. Fishery affirms a score of 4.2 (satisfied), while the industry closely follows with 4.1 and agriculture 3.8. This reveals that economic climate has a more favourable position in the fishery society than in two other areas, although the difference shown is not significant. However, the high number for this indicator has also confirmed that MFI (koperasi) clients in fishery areas have agreed more than any other areas that they feel friendlier climate to develop their interest in business and ecomony (especially for women).

On the aspect of empowering, it is concluded that semi-formal MFIs clients in each area have almost the same level of perception (no significant difference). Fishery produces scores of 62.53; industry has 62.37; agriculture yields 62.50 . Nonetheless, we can observe that the agriculture generates the highest score on the empowering aspects, meaning that clients in that area feel that MFI is well-prepared in providing infrastructures, educations, and trainings, formulating good regulations and institutions, offering incentives and subsidy, as well as creating business opportunity and building cooperation networks with both internal and external parties.

Meanwhile, on the aspect of advocation, it is concluded that semi-formal MFI clients in fishery areas have higher perception in this aspect. Fishery confirms a percentage of $37.22 \%$, while industry and agriculture have a percentage of $35.08 \%$ and $36.92 \%$, respectively. Therefore, clients in fishery areas have agreed that MFI has successfully provided them with mentoring, protection, and advocation, more than 
clients in other areas feel. However, the difference is, again, not significant.

\section{Business Models of MFIs Clients}

This result will discuss business models that the female clients run, especially those who already married and have their own family. It is also related to how they utilitize the fundings and empowerment facilities provided by the semi-formal MFIs (koperasi) to develop their potential. Business models that are desirable by female clients have these characteristics. First, they only require a minimum amount of capital; second, they are durable; third, they are fast-moving; fourth, they focus more on costumers; fifth, they are easy to adapt; sixth, they give contribution to the society's economy; seventh, they are flexible; eighth, they have a set amount of freedom.

Therefore, the clients of semi-formal MFIs prefer business models that produce low risk, for example, those side business that could generate steady income to support their livelihood. In all three areas of fishery, industry, and agriculture, favourable business models among the female clients include grocery, daily-need pedler, fritters seller, bakery, eatery or restaurant, tailor, cellphone plans seller, barbershop and beauty center, toys and kids' needs store, convenience store, etc.

Futhermore, some female clients from the fishery areas work in jobs that cannot be found in other areas, such as market labor, fish labor, fishmonger, cleaners in the market and ships, and fish auction labor.

\section{The Uniqueness of Each Area}

In the empowerment effort done by semi-formal MFIs, it is shown that each area has its own uniqueness in the process of women economic empowerment. That uniqueness is largely influenced by sociological factor in the form of socio-culture construction generated from the long process process of dialectica and society's dynamics. Religious values and socio-culture norms also take part in the interaction to create way of life for the member society. This way of life is used as a guide in solving problems in the society.

Besides sociological factor that forms the character of a society, nature and geographical condition also play an important role. Housewifes in the fishery areas, for example, have more agresif character. They are speculative, consistent, well-diciplined, and durable. That is because the coastal area where they live consists of a harsh and unstable environment.

That is also the case with housewives from the industrial area. The area is characterized by dense residential with people from various social background, high crime rate, and located next to busy commercial district. This has formed individualistic and materialistic people. They are usually aggressive for economic resources and have more alternatives in selecting business models. They also are highly-mobile individuals. Moreover, this area has a good climate for starting a business and offers stability as well as certainty.

On the other hand, housewifes in the agricultural area has undergone marginalization process, massively detracting from the agriculturian way of life. However, the unique characteristic of farmer society is somehow still intact. Agricultural area is dominant with locals who are native to the place, thus the character of harmony, collectivism, strong relationship between neighbours, speculation-avoiding, safety first, and the needs of certainty in life are central in the society. All this uniqueness that each area has will determine the behavior pattern of the clients in utilizing services provided by the semi-formal MFIs.

\section{THEORETICAL IMPLICATION}

This research has found evidences that show women bear more burden of poverty than their male counterparts, especially in a family. Therefore, theoretically, a massive movement to fight poverty is critically needed. This movement also needs to 
accommodate women participation and is democratic. Without the participation of women, the movement will be ineffective and is doomed to fail.

This research has found that female clients of the semi-formal MFIs have unique traits as well as social capitals. Women have tendency to run their business more carefully and are also more cautious. Women who run business in the rural areas tend to be more aware with the risk of fast development, thus they prefer slower business but more sustainable. That finding confirms the reason why non-performing loan is far more common among the men than the women. Therefore, theoretically, semi-formal MFIs needs to increase its women-based target groups.

\section{RESEARCH'S DISADVANTAGES}

This research still has some disadvantages that are quite hard to be bypassed. The disadvantages are related to the data available for the study.

The data gathered in this research are still partials. Informants and respondents give comments and data in separate occasions; they are yet to be involved in limited and focused group discussions.

This research is lacking for data regarding regional geovernment's policies in the effort of developing woman-based semi-formal MFIs. Also, the research has yet to provide government's perspective on the economic empowerment of women, especially in relation to reduce poverty in Tangerang Regency.

\section{CONCLUSIONS}

The research found in rural areas in Tangerang, which looks at three (3) categories of areas (fishery, industry/residence, and agriculture). By using statistical instruments of testing for a difference between means and independent F-test, then in each area are assumed to have their own advantages, disadvantages, and uniqueness in applying empowering process. Moreover, it turns empowerment process does not have significant differences. It describes, aspects of empowerment MFIs in the field there are appropriate standards.

Thus, no significant differences in the process of empowerment was in the field, supported the data, that the scale of loans are relatively small, the scale of the business capacity including monthly income is relatively low, this type of business are similar, the level of demand less varied, the level of expenditure is relatively low, the load relatively small family, and family education level is low, and the accessibility to the members of the MFI is within easy reach.

Then, related to the work done female clients, a highly desirable business characterized by MFI members: only requiring a minimum amount of capital; durable; fast-moving; focusing more on costumers; adaptable; contributing to the society's economy; flexible; having a set amount of freedom.

\section{References}

Altay, A. 2007. "The Challenge for Global Women Poverty: Microfinance (or Microcredit) as a Solution for Women Poverty in Turkey." Presented at International Conference on Globalization and Its Discontents, January, Cortland.

Arsyad, L. 2005. “An Assement of Performance and Sustainability of Microfinance Institutions: A Case Study of Village Credit Institutions in Gianyar, Bali, Indonesia.” Thesis submitted for the Degree of Doctor of Philosophy, Faculty of Social Sciences, Flinders University Adelaide, Australia.

Aruna, M. and R. Jyothirmayi. 2011. “The Role of Microfinance in Women's Empowerment: A Study on the SHG Bank Linkage Program in Hyderabad (Andhara Pradesh).” Indian Journal of Commerce \& Management Studies 2(4):77-95.

Betata, H. C. 2007. "What Is Missing in Measures of Women's Empowerment?” Journal of Human Development $7(2): 221-241$.

Bhatt, N. and S.-Y. Tang. 2001. "Delivering Microfinance in Developing Countries: Controversies and Policy Perspectives.” Policy Studies Journal 29(2):319-333.

BPS (Badan Pusat Statistik/Central Bureau of Statistics). 2011. Annual Report. Jakarta.

Brau, J. B., S. Hiatt, and W. Woodworth. 2009. "Evaluating 
Impact of Microfinance Institutions Using Guatemalan Data.” Managerial Finance 35(12):953-974.

Chambers, R. 2006. "What Is Poverty? Concepts and Measures.” International Poverty Centre. United Nations Development Programme, December.

Chowdhury, M. R., P. Mosley, and A. Simanowitz. 2004. "The Social Impact of Microfinance.” Journal of International Development 16:291-300.

Eyben, R., N. Kabeer, and A. Cornwall. 2008. "Conceptualising Empowerment and the Implications for Poverty Reduction.” Paper for the OECD-DAC Poverty Network.

Gonzalez, A. 2008. How Many Borrowers and Microfinance Institutions (MFIs) Exist? Microfinance Information Exchange. Retrieved March 2012 (http://www.themix. org/publications/microbanking-bulletin/2008/12/how-many -mfis-and-borrowers exist-updated-dec-2008).

Hartungi, R. 2007. "Understanding the Success Factors of Micro-Finance Institution in a Developing Country." International Journal of Social 34(6):231-246.

Ifelunini, I. and E. Wosowei. 2013. "Constraints to Women Entrepreneurs' Access to Microfinance in South-South Nigeria." Research Journal of Finance and Accounting 4(6):6-13.

Jain, D. and B. Jain. 2012. "Does Microfinance Empower Rural Women? A Empirical Study in Udaipur District, Rajasthan.” Journal of Arts, Science \& Commerce 3(2):76-89.

Jupp, D., S. I. Ali, and contribution from C. Barahona. 2010. Measuring Empowerment? Ask Them. Quantifying Qualitative Outcomes From People's Own Analysis. Sida Studies in Evaluation. Commissioned by Sida, Department for Long-Term Program Cooperation, Team for Bangladesh in collaboration with Secretariat for Evaluation. Retrieved (http://www.oecd.org/countries/bangladesh/ 46146440.pdf).

Kabeer, N. 2008. Mainstreaming Gender in Social Protection for the Informal Economy. London: Commonwealth Secretariat.

Kartasasmita, G. 1999. "Power and Empowerment: A Concept of Community Empowerment.” Culture Speech at Anniversary to 28. Jakarta Arts Center-Taman Ismail Marzuki. November 19, Jakarta.

Leikem, K. 2012. "Microfinance: A Tool for Poverty Reduction?” Senior Honors Projects. Paper 300. Retrieved (http://digitalcommons.uri.edu/srhonorsprog/300).

Luttrell, C., S. Quiroz, C. Scrutton, and K. Bird. 2007. Understanding and Operationalising Empowerment. Retrieved (http://preventgbvafrica.org/wp-content/uploads/ 2013/11/resourcessharewebResource_en_1547.pdf).

Mayoux, L. 1999. "Questioning Virtuous Spiral: Micro-Finance and Women's Empowerment in Africa.” Journal of International Development 23:323-334.
Mosley, P. and J. Rock. 2004. "Microfinance, Labour Markets and Poverty in Africa: A Study of Six Institutions.” The Journal of International Development 16(3):467-500.

Noreen, S. 2011. "Role of Microfinance in Empowerment of Female Population of Bahawalpur District." Presented at International Conference on Economics and Finance Research, Singapore.

Prijono and Pranarka. 1996. Empowerment: Concepts, Policy and Implementation. Jakarta: CSIS.

Rajivan, A. 2001. Microcredit and Women Empowerment: A Case Study of SML (SHARE Microfinance Ltd.). United Nations Development Program (UNDP). - 2003. Microcredit and Women's Empowerment: A Case Study of SML (SHARE Microfinance Ltd.). United Nations Development Program (UNDP).

Report of the Ministry of Rural Development (KPDT). 2008. About Desa Maju Categorization, It Forward, Backward and Extremely Backward. Jakarta: KPDT Press.

Rowlands, J. 1997. Questioning Empowerment: Working With Women in Honduras. Oxford: Oxfam Publications.

Rural Poverty Report. 2011. International Fund for Agricultural Development Publications Rural Poverty Report 2011. Retrieved (http://www.ifad.org/rpr2011/ index.htm).

Sakernas (The National Labour Force Survey). 2010. Survei Angkatan Kerja Nasional di Indonesia (National Labour Survey in Indonesia), August.

Schreiner, M. and J. Yaron. 1999. "Development Finance Institutions: Measuring Their Subsidy.” Journal of Microfinance Risk Management 24:74-87.

Shastri, R. K. 2009. "Micro Finance and Poverty Reduction in India (A Comparative Study With Asian Countries)." African Journal of Business Management 3(4):136-140.

Strauss, A. L. and J. Corbin. 1990. Basics of Qualitative Research Grounded Theory Procedures and Techniques. Newbury Park, CA: Sage.

Sumodiningrat, G. 1998. Community Empowerment and Social Safety Net. Jakarta: PT Gramedia Pustaka Utama.

Teddlie, C. and F. Yu. 2007. "Mixed Methods Sampling: A Typology With Examples." Journal of Mixed Methods Research 1(1):77-100. Retrieved (http://www.sage publications.com).

The International Fund for Agricultural Development (IFAD). 2009. National Agribusiness Development Programme. Final Completion Report. Washington, D.C.

The Millennium Development Goals Report. 2010. We Can End Poverty 2015 MDGs. United Nations, New York.

The World Bank, FAO (Food and Agriculture Organization), IFAD (International Fund for Agricultural Development). 2009. Gender in Agriculture Sourcebook (Agriculture and Rural Development). Washington, D.C. 
The World Bank. 2010. "World Development Report, 2010. Prosperity for All. Ending Extreme Poverty.” A Note for the World Bank Group, Spring Meetings 2014. New York: Oxford Universities Press.

Todaro, M. and S. C. Smith. 2006. Economic Development. 9th ed. United Kingdom: Pearson Education Limited.

Tundui, C. S. and B. E. Mgonja. 2010. "Microcredit and Poverty Alleviation Through the Labour Market: Evidence From Women Microcredit Clients in Tanzania.” Global Journal of Human Social Sciences 10(3):69-76.

Velasco, C. and R. Marconi. 2004. “Group Dynamics, Gender and Microfinance in Bolivia.” Journal of International Development 16:519-528.

Williams, S., J. Seed, and A. Mwau. 1994. Oxfam Gender Training Manual. Oxford: Oxfam.

Yin, R. K. 1995. Case Study Research: Design and Methods. Jakarta: Rajawali.

Yunus, M. and A. Jolis. 1999. Banker to the Poor:
Micro-Lending and the Battle Against World Poverty. New York: Public Affair.

\section{Bios}

Mukhaer Pakkanna, Ph.D. candidate, Faculty of Economics and Business Sebelas Maret University (UNS), Surakarta, lecturer, Ahmad Dahlan School of Economics (STIEAD), Jakarta, Indonesia; research fields: economic sociology and rural finance.

Lincolin Arsyad, Ph.D., Professor of Development Economics, Faculty of Economics and Business, Gadjah Mada University (UGM), Yogyakarta, Indonesia; research fields: regional autonomy and microfinance.

Agustinus Suryantoro, Ph.D., lecturer, Faculty of Economics and Business, Sebelas Maret University (UNS), Surakarta, Indonesia; research field: regional developement. 